Research Article

\title{
Anti-inflammatory potential of Agaricus in carrageenan-induced model of local inflammation in rats
}

\author{
Abdelrazzag A. Elmajdoub ${ }^{1}$, Shaban Kh. Awidat ${ }^{1}$, Abubakr M. El-Mahmoudy ${ }^{2 *}$
}

\begin{abstract}
${ }^{1}$ Department of Pharmacology, Toxicology \& Forensic Medicine, Faculty of Veterinary Medicine, University of Tripoli, 13662 Tripoli, Libya, ${ }^{2}$ Department of Pharmacology, Faculty of Veterinary Medicine, Benha University, 13736 Moshtohor, Egypt
\end{abstract}

Received: 13 March 2015 Accepted: 24 April 2015

*Correspondence to: Abubakr M. El-Mahmoudy, Email: a.elmahmoudy@, hotmail.com

Copyright: (C) the author(s), publisher and licensee Medip Academy. This is an openaccess article distributed under the terms of the Creative Commons Attribution NonCommercial License, which permits unrestricted noncommercial use, distribution, and reproduction in any medium, provided the original work is properly cited.

\begin{abstract}
Background: The concept of effects of Agaricus on inflammatory responses is still controversial. This study, therefore, was designed to assess the potential of the anti-inflammatory effect of Agaricus $100 \%$ extract on acute inflammation using the model of carrageenan-induced paw edema in rats.

Methods: Four groups among five (six rats each) have been injected with carrageenan ( $0.1 \mathrm{~mL}$ of $3 \%$ solution), intra-plantar in the right hind paw; the first group was injected with saline instead in the same manner and kept as control. An hour earlier, rats received different treatments, either saline (inflamed control), or diclofenac (inflamed, standard-treated), or Agaricus extract $(5 \mathrm{~mL} / \mathrm{kg}$ as small dose or $10 \mathrm{~mL} / \mathrm{kg}$ as a large dose). The volume of the developed paw edema has been measured at an hour interval fashion (1 6 hrs) and at $24 \mathrm{hrs}$.

Results: Agaricus extract showed inhibitory effects on the carrageenan-induced edema in time- and dose-dependent manner, at the late phase $(2 \sim \mathrm{hrs})$ of the inflammatory response (small dose) and at both early ( $\sim 2 \mathrm{hrs}$ ) and late phases (large dose). The effects were comparable to those of diclofenac being 11.74, 08.46, $08.99,09.72$ and $09.89 \%$ at $2-6$ hrs (small dose); 14.04, 23.91, 21.92, 17.99, 15.63 and $16.96 \%$ at $1-6 \mathrm{hrs}$ (large dose); 16.85, 31.30, 35.38, 35.97, 34.72 and 34.63\% (diclofenac). The anti-inflammatory effect of Agaricus could be attributed to its phytochemical content which may inhibit the inducible inflammatory mediators (as prostaglandins and nitric oxide) in the late phase (small dose) and/or inhibiting both early (histamine and oxygen free radicals) and late mediators (large dose).

Conclusions: These data may indicate that Agaricus extract has the potential of anti-inflammatory activity that could be applied in acute inflammatory disorders.
\end{abstract}

Keywords: Agaricus, Anti-inflammatory, Natural, Herbal, Ethnopharmacology

\section{INTRODUCTION}

Inflammation is the body's immediate response to damage to its tissues and cells by pathogens, noxious stimuli such as chemicals, thermal stimuli, physical injury or antigen-antibody reaction. The overall process, in a broad perspective, is a useful one, its primary significance is defense. However, more precisely, this is not always the case. Acute inflammation is a short-term response that usually results in healing: leukocytes infiltrate the damaged region, removing the stimulus and repairing the tissue. Chronic inflammation, in contrast, is a prolonged, dysregulated and maladaptive response that involves active inflammation, tissue destruction and attempts at tissue repair. Such persistent inflammation is associated with many chronic human conditions and diseases, including allergy, atherosclerosis, cancer, arthritis and autoimmune diseases. ${ }^{1,2}$

Various mediators are known to be involved in the inflammatory reactions including prostaglandins, 5-hydroxytryptamine, histamine, and bradykinin, in addition to fluid extravasations and cellular infiltration. The inflammatory injury may be attributed, in part, to the release of reactive oxygen species from activated neutrophil and macrophages. This over production leads to tissue injury damaging the macromolecules and lipid peroxidation of membranes. ${ }^{3}$ 
Many chemical-based remedies are established with valuable efficacies including methylsalicylates, indoles, propionates and others, but their side effects are also well established including gastric and renal ones. Therefore, when applicable, replacing with herbal based remedies becomes a valuable issue for safety and efficacy as well.

Agaricus blazei murrill is a mushroom originally native to a small village in Brazil. It was discovered in 1960 by Takatoshi Furumoto, a grower, and researcher, who sent it to Japan in 1965 for investigation. It was identified as ABM by the Belgian botanist Heinemann in $1967 .^{4}$

Botanically, Agaricus is a genus belonging to the family Agariaceae, ${ }^{5}$ and is generally described as having small to large fruit bodies with white, yellow or brown pileus; free lamellae that are pallid or pinkish when young, later becoming chocolate brown; and also dark-brown, smooth basidiospores. $^{6}$

Phytochemically, the general gross composition of mushrooms is water $(90 \%)$, protein $(2-40 \%)$, fat $(2-8 \%)$, carbohydrates (1-55\%), fiber (3-32\%) and ash (8-10\%). The active contents can be isolated from fruiting bodies, pure culture mycelia and culture filtrate. Agaricus fruiting bodies in different stages of maturity contain glucans ( $\alpha$ and $\beta$ types) that are thought to be responsible for its pharmacological actions; the yield and structural diversity of glucans increase as the fruiting bodies mature; hence the time of the harvest and conservation is of great importance, to obtain the best extract.

The mushroom is traditionally believed to fight physical and emotional stress, stimulate immune system, improve the quality of life in diabetics, reduce cholesterol, prevent osteoporosis and peptic ulcer, treat circulatory and digestive problems and fight cancer. ${ }^{4}$

Nowadays, many companies and cultivation centers are producing Agaricus and many commercialized products are established, especially in Japan, China, and Brazil. The present study was designed to evaluate the anti-inflammatory potential of one of the commercialized Agaricus products as a trial to find out the scientific basis, which may support its ethnopharmacological use.

\section{METHODS}

\section{Plant material and drugs}

Agaricus used in the present study was obtained as a commercially produced preparation in the form of bottles containing $50 \mathrm{~mL}$ of $100 \%$ extract. Carrageenan was purchased from Sigma-Aldrich (St. Louis, MO, USA). Diclofenac was used as Voltaren ${ }^{\circledR}$ oral tablets containing $50 \mathrm{mg}$ of diclofenac sodium (Novartis ${ }^{\circledR}$, Basel, Switzerland).

\section{Experimental animals}

Male Wistar rats (180-210 g) were used. They were housed in a room with controlled temperature $\left(22 \pm 1^{\circ} \mathrm{C}\right)$, humidity $(60 \pm 10 \%)$ and light (12 hrs/day) for at least a week before being used. Food and water were available ad libitum. Animal care was in accordance with Guidelines for Care and Use of Laboratory Animals in Biomedical Research of the National Institutes of Health of the United States, ${ }^{7}$ and approved by our Institutional Committee of Experimentation Ethics on Animal Use.

\section{Carrageenan-induced paw edema}

The method described by ${ }^{8}$ was used to evaluate the anti-inflammatory activity of Agaricus with some minor modifications. The rats were allocated into five groups (six animals each) and fasted overnight the day before the day of the experiment. An hour before induction of inflammation by intra-planter administration of $0.1 \mathrm{~mL}$ of carrageenan solution $(3 \% \mathrm{w} / \mathrm{v}$ in saline) in the right hind paw of all animals (except those of Group I), the groups received the following pretreatments:

- Group I received normal saline $(5 \mathrm{ml} / \mathrm{kg}$, orally; $1 \mathrm{~mL} / \mathrm{rat}$ weighing $200 \mathrm{~g}$ ) using a suitable sized stomach tube. Animals of this group did not receive carrageenan but was injected with $0.1 \mathrm{~mL}$ saline into the planter region of the right hind paw instead, and was kept as normal control.

- Group II received normal saline ( $5 \mathrm{~mL} / \mathrm{kg}$, orally) an hour prior carrageenan injection into the right hind paw and was kept as inflamed control.

- Groups III and IV received Agaricus extract (5 and $10 \mathrm{~mL} / \mathrm{kg}$, respectively, orally) an hour prior carrageenan injection into the right hind paw and was kept as an inflamed-tested group.

- Group V received the standard drug diclofenac sodium (100 $\mathrm{mg} / \mathrm{kg}$, orally) an hour prior to carrageenan injection into the right hind paw and was kept as an inflamed-standard-treated group.

The anti-inflammatory activity was indicated in terms of paw edema volume (in $\mathrm{mL}$ ) that was measured using plethysmometer (7140, Ugo Basile s.r.l., Varese, Italy) immediately after the injection and subsequently at 60 mins intervals for up to $6 \mathrm{hrs}$. A mark was made around the right hind paws just below the tibio-tarsal joint so that the paw could be dipped equally every time into the dipping tube of the plethysmometer up to that mark.

The anti-inflammatory activity of both standard and tested agents was calculated as percent of inhibition of edema volume at every time point using the following equation:

$\%$ Inhibition $=([$ Predrug reading - Postdrug reading $] /$ Predrug reading $) \times 100$ 


\section{Statistical analysis}

The values were expressed as the mean \pm standard error mean of $n$ observations, where $n$ represents the number of animals studied in each group. The data were analyzed using one-way Analysis of Variance (ANOVA), followed by the least significant difference post-hoc test for multiple comparisons. Differences were considered significant at $\mathrm{p}<0.05$. The means, and comparisons were calculated using SPSS v.20 software (Chicago, USA). Of primary importance, comparing Group II to Group I to ensure the success of inflammation model; secondly, comparing Groups III and IV to Group II to evaluate the anti-inflammatory activity of Agaricus. The activity of Agaricus was standardized as a percentage of that of the standard anti-inflammatory drug, diclofenac.

\section{RESULTS}

As a rule, the standard drug diclofenac at the dose of $100 \mathrm{mg} / \mathrm{kg}$ significantly $(\mathrm{p}<0.01)$ decreased the volume of hind paw edema through all time-points (1 6), with percentage of inhibition by $16.85,31.30,35.38,35.97,34.72$ and 34.63 , respectively, when compared with the inflamed control. Agaricus at the dose of $5 \mathrm{~mL} / \mathrm{kg}$ of the $100 \%$ extract significantly $(p<0.01)$ reduced the volume of paw edema only from $2 \mathrm{hrs}$ and afterwards with inhibition percentage of $11.74,08.46,08.99,09.72$ and $09.89 \%$, respectively; whereas at the dose of $10 \mathrm{~mL} / \mathrm{kg}$, it significantly $(p<0.01)$ reduced the volume of paw edema through all time-points (1 6), with percentage of inhibition by 14.04, 23.91, 21.92, $17.99,15.63$ and $16.96 \%$, respectively, after administration when compared with the inflamed control. The overall mean anti-inflammatory effects of diclofenac, Agaricus small dose and Agaricus large dose were $31.48 \pm 7.35,9.35 \pm 1.50$ and $18.41 \pm 3.79 \%$, respectively. All of the recorded results are presented in Tables 1 and 2, Figure 1.

\section{DISCUSSION}

Inflammation of a tissue represents a reaction by its cells and its microcirculation to the inflammatory mediators released upon exposure to inflammatory agents, including microbial or chemical or physical ones. This reaction could be identified clinically by five cardinal signs including redness, hotness, swelling, pain and loss of functions. These endogenous inflammatory mediators include histamine, serotonin, bradykinin, prostaglandins, leukotrienes and cytokines, which are responsible for vasodilation, chemotaxis and increase in vascular permeability. ${ }^{9}$

The carrageenan-induced paw edema is a widely used test to determine anti-inflammatory activity and constitutes a simple and routine animal model for evaluation of pain at the site of inflammation without any injury or damage to the inflamed paw. ${ }^{10}$ Carrageenan is derived from a number of red seaweeds of the class Rhodophyceae. It is a sulfated polygalactan with $15-40 \%$ of the ester-sulfate content and an average relative molecular mass well above $100 \mathrm{kDa}$. The chemical reactivity of carrageenan is primarily due to its ester-sulfate groups which are strongly anionic. ${ }^{11}$ Carrageenan-developed edema has been described pathophysiologically as a "biphasic" event to which various mediators contribute in sequence to produce the resultant inflammatory response. Histamine, serotonin, and bradykinin are the first detectable mediators in the early phase $(1 \sim 2 \mathrm{hrs})$ of carrageenan-induced inflammation; prostaglandins are involved in the increased vascular permeability and are detectable in the late phase ( $2 \sim 6 \mathrm{hrs}$ ) of inflammation. In addition, enhanced levels of the pro-inflammatory cytokines tumor necrosis factor- $\alpha$ (TNF- $\alpha$ ), interleukin (IL-1), and IL-6 have been proved to be associated with the response. ${ }^{12}$ The initial phase of is inhibited mainly by anti-allergics and anti-oxidants, while the second accelerating phase of swelling is inhibited mainly by nonsteroidal anti-inflammatory drugs as it is attributed to the extra prostaglandin synthesis via inducible cyclooxygenase

Table 1: Effects of Agaricus 100\% extract ( 5 and $10 \mathrm{~mL} / \mathrm{kg}$, orally) and diclofenac sodium (100 mg/kg, orally) on paw edema $(\mathrm{mL})$ induced by carrageenan $(0.1 \mathrm{~mL}$ of $3 \%$ solution, intra-plantar $)$ in rats $(\mathrm{mean} \pm \mathrm{SEM} ; \mathrm{n}=6)$.

\begin{tabular}{|c|c|c|c|c|c|}
\hline Groups & G1, control & G2, inflamed & G3, standard & G4, tested SD & G5, tested LD \\
\hline $\begin{array}{l}\text { Treatment } \\
\text { (dose, per Os) }\end{array}$ & $\begin{array}{c}\text { Saline } \\
(5 \mathrm{~mL} / \mathrm{kg})\end{array}$ & $\begin{array}{c}\text { Saline } \\
(5 \mathrm{~mL} / \mathrm{kg})\end{array}$ & $\begin{array}{l}\text { Diclofenac } \\
(100 \mathrm{mg} / \mathrm{kg})\end{array}$ & $\begin{array}{l}\text { Agaricus } \\
(5 \mathrm{~mL} / \mathrm{kg})\end{array}$ & $\begin{array}{l}\text { Agaricus } \\
(10 \mathrm{~mL} / \mathrm{kg})\end{array}$ \\
\hline \multicolumn{6}{|c|}{$\begin{array}{l}\text { Mean paw edema at } \\
\text { different time points }(\mathrm{mL})\end{array}$} \\
\hline $0 \mathrm{hr}$ & $1.40 \pm 0.041$ & $1.40 \pm 0.041$ & $1.40 \pm 0.041$ & $1.38 \pm 0.048$ & $1.40 \pm 0.041$ \\
\hline $1 \mathrm{hr}$ & $1.43 \pm 0.25$ & $1.78 \pm 0.063 *$ & $1.48 \pm 0.048^{\times}$ & $1.65 \pm 0.065$ & $1.53 \pm 0.025^{\times}$ \\
\hline $2 \mathrm{hrs}$ & $1.48 \pm 0.048$ & $2.30 \pm 0.108 *$ & $1.58 \pm 0.048^{\times}$ & $2.03 \pm 0.048^{\times}$ & $1.75 \pm 0.029^{\times}$ \\
\hline $3 \mathrm{hrs}$ & $1.53 \pm 0.025$ & $2.60 \pm 0.091 *$ & $1.68 \pm 0.048^{\times}$ & $2.38 \pm 0.026^{\times}$ & $2.03 \pm 0.048^{\times}$ \\
\hline $4 \mathrm{hrs}$ & $1.55 \pm 0.029$ & $2.78 \pm 0.111^{*}$ & $1.78 \pm 0.048^{\times}$ & $2.53 \pm 0.025^{\times}$ & $2.28 \pm 0.048^{\times}$ \\
\hline $5 \mathrm{hrs}$ & $1.55 \pm 0.029$ & $2.88 \pm 0.063 *$ & $1.88 \pm 0.048^{\times}$ & $2.60 \pm 0.041^{\times}$ & $2.43 \pm 0.063^{\times}$ \\
\hline $6 \mathrm{hrs}$ & $1.55 \pm 0.029$ & $2.83 \pm 0.025 *$ & $1.85 \pm 0.050^{\times}$ & $2.55 \pm 0.029^{\times}$ & $2.35 \pm 0.096^{\times}$ \\
\hline $24 \mathrm{hrs}$ & $1.48 \pm 0.025$ & $1.56 \pm 0.048$ & $1.43 \pm 0.025$ & $1.50 \pm 0.041$ & $1.50 \pm 0.041$ \\
\hline
\end{tabular}

*Significantly different from control, ${ }^{\times}$Significantly different from inflamed $(\mathrm{p}<0.05$; ANOVA followed by LSD test), ANOVA: Analysis of variance, LSD: Least significant difference, SEM: Standard error of mean 
Table 2: Inhibition percent of Agaricus $100 \%$ extract (5 and $10 \mathrm{~mL} / \mathrm{kg}$, orally) and diclofenac sodium $(100 \mathrm{mg} / \mathrm{kg}$, orally) on paw edema $(\mathrm{mL})$ induced by carrageenan $(0.1 \mathrm{~mL}$ of $3 \%$ solution, intra-plantar) in rats $(n=6)$.

\begin{tabular}{|c|c|c|c|}
\hline Groups & G3 & G4 & G5 \\
\hline $\begin{array}{l}\text { Treatment } \\
\text { (Dose, per Os) }\end{array}$ & $\begin{array}{l}\text { Diclofenac } \\
\text { (100 mg/kg) }\end{array}$ & $\begin{array}{l}\text { Agaricus } \\
(5 \mathrm{~mL} / \mathrm{kg})\end{array}$ & $\begin{array}{c}\text { Agaricus } \\
(10 \mathrm{~mL} / \mathrm{kg})\end{array}$ \\
\hline \multicolumn{4}{|l|}{$\begin{array}{l}\text { Protection } \\
\text { percent }(\%)\end{array}$} \\
\hline $0 \mathrm{hr}$ & NA & NA & NA \\
\hline $1 \mathrm{hr}$ & $16.85^{\times}$ & 07.30 & $14.04^{x}$ \\
\hline $2 \mathrm{hrs}$ & $31.30^{\times}$ & $11.74^{\times}$ & $23.91^{\times}$ \\
\hline $3 \mathrm{hrs}$ & $35.38^{x}$ & $08.46^{\times}$ & $21.92^{\times}$ \\
\hline $4 \mathrm{hrs}$ & $35.97^{\times}$ & $08.99^{\times}$ & $17.99^{\times}$ \\
\hline $5 \mathrm{hrs}$ & $34.72^{x}$ & $09.72^{x}$ & $15.63^{\times}$ \\
\hline $6 \mathrm{hrs}$ & $34.63^{\times}$ & $09.89^{\times}$ & $16.96^{\times}$ \\
\hline $24 \mathrm{hrs}$ & NA & NA & NA \\
\hline Mean \pm SD (\%) & $31.48 \pm 7.35$ & $9.35 \pm 1.50$ & $18.41 \pm 3.79$ \\
\hline
\end{tabular}

${ }^{\times}$Significantly different from Inflamed $(\mathrm{p}<0.05$; ANOVA followed by LSD test); NA: Non-applicable, ANOVA: Analysis of Variance, LSD: Least significant difference

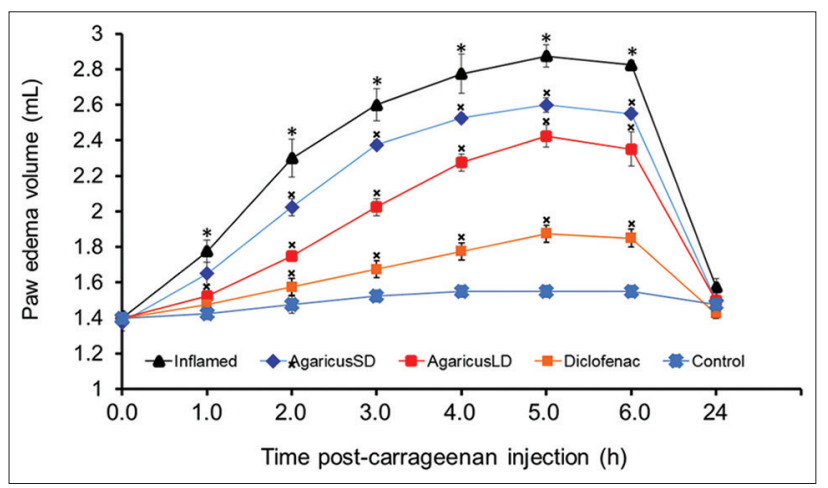

Figure 1: Histogram showing the effects of Agaricus $100 \%$ extract (5 and $10 \mathrm{~mL} / \mathrm{kg}$, orally) and diclofenac sodium $(100 \mathrm{mg} / \mathrm{kg}$, orally) on paw edema $(\mathrm{mL})$ induced by carrageenan $(0.1 \mathrm{~mL}$ of $3 \%$ solution, intra-plantar) in rats (Mean \pm standard error of the mean; $\mathbf{n = 6 ) . ~ * S i g n i f i c a n t l y ~ d i f f e r e n t ~ f r o m ~ c o n t r o l , ~}$ $\times$ Significantly different from inflamed $(p<0.05$; Analysis of Variance followed by least significant difference test).

(COX-2) in the hind paw. ${ }^{13}$ Local neutrophil infiltration and activation also contribute to this inflammatory response by producing, among other mediators, oxygen-free radicals $\left(\mathrm{O}^{2-}\right)$ and hydroxyl $\left(\mathrm{OH}^{-}\right)$radicals. ${ }^{14}$ Also, the activated polymorphonuclear leukocytes release the lysosomal enzymes and active oxygen radicals, especially superoxide to destroy connective tissues and induce paw swelling. ${ }^{15}$ Additional important mediator in acute inflammation is nitric oxide (NO), which is produced by physiologically by two distinct isoforms of NO synthases (NOS): endothelial NOS and neuronal NOS (nNOS); and pathologically by inducible
NOS (iNOS). Findings after neuroectomy or application of NOS inhibitors indicate that nNOS contributes to the NO production in both the early and late phase, and that iNOS only contributes to the late phase. ${ }^{16}$

Hence, the impending release of one or more of these mediators at injured sites or impeding them from bringing out their pathological effects would logically ameliorate the inflammatory reaction and its symptoms.

In the last decades, the mushroom has been studied as a novel functional food and its hot-water soluble fractions were used as a medicine in the Far East. The first historical description about the use of mushroom of Agaricus genus for medicinal purposes is probably described by Byzantine medical treatises in the Mediterranean area by Orivasios and Apuleius for treating malignant ulcers of the larynx. ${ }^{17}$ The mushroom was traditionally used to treat many common diseases such as atherosclerosis, hepatitis, hyperlipidemia, diabetes, dermatitis and cancer although the biological pathways and chemical substances involved in its pharmacological activities are still not clear. In-vitro and in-vivo, Agaricus has shown immunomodulatory and antimutagenic properties..$^{18}$

In the present study, Agaricus at doses of 5 and $10 \mathrm{~mL}$ of $100 \%$ extract $/ \mathrm{kg}$ significantly exhibited a dose- and time-dependent sustained inhibition of the rat paw edema in the second phase (small dose) and in both phases (large dose) of its development. Although the exact mechanism of the observed anti-inflammatory activity needs further investigations, yet it might be attributed to one or more of its phytochemical active constituents that may have ability to inhibit the biosynthesis of prostaglandins which is consistent with the observation of the used standard anti-inflammation drug diclofenac. Another hypothesis is the decreased production of oxygen free radicals and histamine by the infiltrating leucocytes and/or affected cells of the paw.

The first hypothesis could be supported by data reported by ${ }^{19}$ who reported that treatment of rats with $A$. blazei during 15 days had an inhibitory action on nociceptive response and acute inflammation induced by formalin injection. The inhibitory protective effect was indicated by that rats treated with Agaricus had a lower number of paw movements during the late phase which is related to the induced mediators of the acute inflammatory process including $\mathrm{NO}$ and prostaglandins.

Our data also are consistent with ${ }^{20}$ who reported that the treatment with $A$. blazei alkaline (300, 400, and $500 \mathrm{mg} / \mathrm{kg}$ ) and aqueous $(300,400$, and $500 \mathrm{mg} / \mathrm{kg}$ ) extracts inhibited edema formation by $19 \%, 33 \%, 39 \%, 12 \%, 38 \%$, and $56 \%$, respectively, compared to the control group in rat paw edema induced by nystatin. Furthermore, administration of extracts inhibited neutrophil migration to the exudates present in the peritoneal cavity after carrageenan injection. The authors concluded that it was possible that Agaricus extracts can be useful in inflammatory diseases because of modulation of 
the immune system and its cells induced by the presence of polysaccharides such as $\beta$-glucans.

Additional support may come from data reported by ${ }^{21}$ who found that the chloroform-soluble extract of Agaricus inhibited the production of IL-6, prostaglandin D2 and leukotriene C4 in stimulated bone marrow-derived mast cells, demonstrated inhibition of the degranulation of $\beta$-hexosaminidase and down-regulated the phosphorylation of Akt. They concluded that the chloroform-soluble extract of $A$. blazei exerted antiinflammatory and anti-allergic activities.

The second hypothesis could be supported by the finding of $^{22}$ who reported that Agaricus has been demonstrated to contain thermo-stable, potent antioxidant substances, since the extract was prepared by boiling the mushroom in water for $120 \mathrm{mins}$ and autoclaving. Some other studies also proved the free radical scavenging ability of Agaricus including, ${ }^{23}$ who reported that the electro-active chemical composition, and oxidation potentials of Agaricus were more positive than those of the used standards, ascorbic and gallic acids; and ${ }^{24}$ who compared the antioxidant power of methanolic extracts sourced from young and mature Agaricus, they found that both extracts showed similar antioxidant activities, except for the chelating ability for ferrous ions, that was higher in extract of mature Agaricus, they supported the use of both young and mature fruiting bodies of Agaricus as sources of antioxidant compounds.

The inhibitory effect of Agaricus (particularly in large dose) against early mediators of the inflammatory response could be supported by ${ }^{25}$ who reported that Agaricus extract dose-dependently inhibited compound 48/80-induced or anti-dinitrophenyl IgE-mediated histamine release from rat peritoneal mast cells.

On the other hand, various studies showed that the effect of Agaricus on the immune system including inflammatory cytokines and components are antithetical. For instance, water extracts of the mycelial culture and fruiting bodies markedly induced TNF, IL-8 and NO by macrophages derived from rat bone-marrow. ${ }^{26}$ Other extracts have shown, on the contrary, a down-regulation of IL-2, IL-4 and INF- $\gamma$ in human peripheral blood mononuclear cells has also been documented. ${ }^{27}$

A study using 9\% solution of an aqueous Agaricus extract, was undertaken by ${ }^{28}$ to determine changes of gene expression caused by the extract on a human monocyte cell line; and they found out drastic effects on gene expression: genes related to immune function were selectively up-regulated, particularly pro-inflammatory genes such as the IL- $1 \beta$ and IL-8. Although most genes-induced by Agaricus were also induced by lipopolysaccharide, yet, Agaricus produced a particular increase in mRNA for the chemokine ligands 1, 2 and 3, IL-1A, as well as COX-2.

These discrepancies are probably attributed to the different types and compositions of used extracts and, thus, a better definition of active principles in Agaricus is needed to explain its various actions and their mechanisms on cells and interactions with cellular physiological processes.

From this study, it could be concluded that Agaricus has the potential of anti-inflammatory activity possibly by a mechanism involving inhibition of inflammatory mediators mainly in the late phase of inflammatory response; and in both early and late phases in larger doses.

Funding: No funding sources

Conflict of interest: There is no actual or potential conflict of interest in relation to this article

Ethical approval: The experimental procedures conducted in the present study were approved by our institutional committee of Experimentation Ethics on Animal Use

\section{REFERENCES}

1. Weiss U. Inflammation. Nature. 2008;454(7203):427.

2. Ryan GB, Majno G. Acute inflammation. A review. Am J Pathol. 1977;86(1):183-276.

3. Lavanya R, Maheshwari S, Harish G, Raj J, Kamali S, Hemamalani $\mathrm{D}$, et al. Investigation of in vitro antiinflammatory, anti-platelet and anti-arthritic activities in the leaves of Anisomeles malabarica Linn. Res J Pharm Biol Chem Sci. 2010;1(4):745-52.

4. Mizuno T. Kawariharatake, Agaricu blazei Murill: medicinal and dietary effects. Food Rev Int. 1995;11(1):167-72.

5. Cappelli A. Fungi europaei. In: Kirk PM, Cannon PF, Minter DW, Stalpers JA, editors. Agaricus L. Fr ss. Karsten (Psalliota Fr.). Vol. 1. Saronno, Italy: Libreria Editrice Biella Giovanna; 1984.

6. Geml J, Geiser DM, Royse DJ. Molecular evolution of Agaricus species based on ITS and LSU rDNA sequences. Mycol Prog. 2004;3(2):157-76.

7. NIH. Guide for the Care and use of Laboratory Animals. Committee on Care Use of Laboratory Animals. Division of Research Resources. Institute of Laboratory Animal Resources: National Academies; 1985.

8. Winter CA, Risley EA, Nuss GW. Carrageenin-induced edema in hind paw of the rat as an assay for antiiflammatory drugs. Proc Soc Exp Biol Med. 1962;111:544-7.

9. Porth C. Essentials of Pathophysiology: Concepts of Altered Health States. Philadelphia: Wolters Kluwer/Lippincott Williams \& Wilkins; 2011.

10. Jain N, Patil C, Singh A, Kulkarni S. A simple technique to evaluate inflammatory pain along with anti-inflammatory studies in carrageenan-induced paw edema. Indian J Pharmacol. 2001;33(2):114.

11. Necas J, Bartosikova L. Carrageenan: a review. Vet Med. 2013;58(4):187-205.

12. Cuzzocrea S, Sautebin L, De Sarro G, Costantino G, Rombolà L, Mazzon E, et al. Role of IL-6 in the pleurisy and lung injury caused by carrageenan. J Immunol. 1999;163(9):5094-104.

13. Nantel F, Denis D, Gordon R, Northey A, Cirino M, Metters KM, et al. Distribution and regulation of cyclooxygenase-2 in carrageenan-induced inflammation. Br J Pharmacol. 1999;128(4):853-9.

14. Salvemini D, Wang ZQ, Wyatt PS, Bourdon DM, Marino MH, Manning PT, et al. Nitric oxide: a key mediator 
in the early and late phase of carrageenan-induced rat paw inflammation. Br J Pharmacol. 1996;118(4):829-38.

15. Vinegar R, Schreiber W, Hugo R. Biphasic development of carrageenin edema in rats. J Pharmacol Exp Ther. 1969;166(1):96-103.

16. Omote $\mathrm{K}$, Hazama $\mathrm{K}$, Kawamata $\mathrm{T}$, Kawamata $\mathrm{M}$, Nakayaka Y, Toriyabe M, et al. Peripheral nitric oxide in carrageenan-induced inflammation. Brain Res. 2001;912(2):171-5.

17. RamoutsakiIA,Papadakis CE, Ramoutsakis IA, Helidonis ES Therapeutic methods used for otolaryngological problems during the Byzantine period. Ann Otol Rhinol Laryngol. 2002;111(6):553-7.

18. Firenzuoli F, Gori L, Lombardo G. The Medicinal Mushroom Agaricus blazei Murrill: review of literature and pharmacotoxicological problems. Evid Based Complement Alternat Med. 2008;5(1):3-15.

19. Carvalho CD, Alves NC, Monteiro AC, Pelógia NC Antinociceptive and anti-inflammatory effect of Agaricus blazei Murill in rats submitted to the modified formalin test. Rev Dor. 2011;12(1):35-8.

20. Padilha MM, Avila AA, Sousa PJ, Cardoso LG, Perazzo FF, Carvalho JC. Anti-inflammatory activity of aqueous and alkaline extracts from mushrooms (Agaricus blazei Murill). J Med Food. 2009;12(2):359-64.

21. Song HH, Chae HS, Oh SR, Lee HK, Chin YW. Antiinflammatory and anti-allergic effect of Agaricus blazei extract in bone marrow-derived mast cells. Am J Chin Med. 2012;40(5):1073-84.

22. Izawa $\mathrm{S}$, Inoue $\mathrm{Y}$. A screening system for antioxidants using thioredoxin-deficient yeast: discovery of thermostable antioxidant activity from Agaricus blazei Murill. Appl Microbiol Biotechnol. 2004;64(4):537-42.
23. Barros L, Falcão S, Baptista P, Freire C, Vilas-Boas M, Ferreira IC. Antioxidant activity of Agaricus sp. mushrooms by chemical, biochemical and electrochemical assays. Food Chem. 2008;111(1):61-6.

24. Soares AA, de Souza CGM, Daniel FM, Ferrari GP, da Costa SMG, Peralta RM. Antioxidant activity and total phenolic content of Agaricus brasiliensis (Agaricus blazei Murril) in two stages of maturity. Food Chem. 2009;112(4):775-81.

25. Choi $\mathrm{YH}$, Yan $\mathrm{GH}$, Chai $\mathrm{OH}$, Choi $\mathrm{YH}$, Zhang $\mathrm{X}$, Lim JM, et al. Inhibitory effects of Agaricus blazei on mast cell-mediated anaphylaxis-like reactions. Biol Pharm Bull. 2006;29(7):1366-71.

26. Sorimachi K, Akimoto K, Ikehara Y, Inafuku K, Okubo A, Yamazaki S. Secretion of TNF-alpha, IL-8 and nitric oxide by macrophages activated with Agaricus blazei Murill fractions in vitro. Cell Struct Funct. 2001;26(2):103-8.

27. Sorimachi K, Akimoto K, Niwa A, Yasumura Y. Delayed cytocidal effect of lignin derivatives on virally transformed rat fibroblasts. Cancer Detect Prev. 1997;21(2):111-7.

28. Ellertsen LK, Hetland G, Johnson E, Grinde B. Effect of a medicinal extract from Agaricus blazei Murill on gene expression in a human monocyte cell line as examined by microarrays and immuno assays. Int Immunopharmacol. 2006;6(2):133-43.

doi: $10.18203 / 2319-2003 . i j b c p 20150028$

Cite this article as: Elmajdoub AA, Awidat SK,

El-Mahmoudy AM. Anti-inflammatory potential of Agaricus in carrageenan-induced model of local inflammation in rats.

Int J Basic Clin Pharmacol 2015;4:497-502. 